\title{
Empowering and Protecting Local Products: The Implementation of SMEs Product Protection and Legality in Lerep Village Indonesia
}

Muhammad Reza Maulana ${ }^{1} \bowtie$, Fauziah Ramadhani $^{2}$, Aprila Niravita $^{3}$, Sri Lestari $^{4}$

1,2,3 Faculty of Law, Universitas Negeri Semarang, Indonesia

${ }^{4}$ Kantor Desa Lerep, Ungaran, Kab. Semarang, Indonesia

Corresponding author: aprilaniravita@mail.unnes.ac.id

Abstract: The size of the contribution of MSMEs in supporting the economy of a country so that the existence of MSMEs is highly expected by any country because of its vital role in the development and progress of the economy to achieve people's welfare. The establishment of a business in the MSME sector is able to absorb the number of workforces who are ready to work but have not yet got a job so that it can reduce the number of unemployed. In establishing a business, MSME actors should have a legality license or business license to run their business. The importance of legality for MSME activists is that in running their business entrepreneurs do not need to be confused when their merchandise or business is tested to find out the feasibility and legality of the business they are running. Implementation in the ease of granting permits for MSMEs is still not possible in all regions because there are still regional heads who have not issued regulations to delegate the authority to issue MSMEs permits to sub-districts. Business licenses or MSMEs that have received a legality of their products to get it easier in running their business. Business licensing provisions that need to be owned by entrepreneurs in the form of SIUP are based on the Regulation of the Minister of Trade (Permendag) No. 46/2009 concerning Amendments to Permendag No.36 / 2007 concerning Issuance of Trading Business Permits.

Keywords: MSMEs, Product Legality, Local Product

How to cite:

Maulana, M. R., Ramadhani, F., Niravita, A., \& Lestari, S. (2021). Empowering and Protecting Local Products: The Implementation of SMEs Product Protection and Legality in Lerep Village Indonesia. Indonesian Journal of Advocacy and Legal Services, 3(2), 207-216. https://doi.org/10.15294/ijals.v3i2.45844 


\section{A. Introduction}

Micro, Small and Medium Enterprises or what can be abbreviated as MSMEs is a policy made by the Government in the economic sector, which is a business activity capable of expanding employment, providing broad economic services to the community and also playing a role in the process of equalization and increasing income society and promote economic growth and play a role in realizing national stability. UMKM is a trading business which is managed by a business entity or individual which refers to a productive economic business in accordance with the criteria stipulated in the laws and regulations. This is in accordance with the understanding of MSMEs as stated in Law Number 20 of 2008 concerning Micro, Small and Medium Enterprises, which explains that "MSMEs are trading businesses managed by individuals who refer to productive economic enterprises with the criteria stipulated in the Law".

In Law No. 20 of 2008 concerning Micro, Small and Medium Enterprises, there is a general explanation which says that national development aims to create a just and prosperous society that is evenly distributed both materially and spiritually based on Pancasila and the 1945 Constitution of the Republic of Indonesia.

Micro enterprises based on Law Number 20 of 2008 are independent productive economic business opportunities which are carried out by individuals or business entities that are not subsidiaries or are not branches of companies that are owned, controlled or become part of the business directly or indirectly. medium or large businesses that meet the criteria for small businesses as referred to in this law.

Then what is meant by medium enterprises according to Law no. 20 of 2008, namely "productive economic enterprises that stand alone, which are carried out by individuals or business entities that are not subsidiaries or branches of companies that are owned, controlled or become part of either directly or indirectly with Small or Large Businesses with total assets. net or annual sales proceeds as regulated in this Law".

So that based on the definition above, based on the Law on MSMEs we can conclude the characteristics of micro, small and medium enterprises, namely: ${ }^{1}$

Irfani \& Nurmaya Safitri, “ Perizinan Terhadap Usaha Mikro Kecil Menengah (UMKM) Yang Melakukan Pencemaran Lingkungan”, Jurnal Al'Adl Volume XII No. 2, 2020. 
1. The type of goods / commodity of the business is not always fixed, may change at any time;

2. The place of business is not always permanent, it can move from time to time;

3. Not even simple financial administration, and not separating family finances from business finances;

4. Human resources (entrepreneurs) do not have an adequate entrepreneurial spirit;

5. The average level of education is relatively very low;

6. Generally they do not have access to banking, but some of them have access to non-bank financial institutions;

7. Generally do not have business license or other legality requirements including NPWP.

In the Indonesian economy, MSMEs are a form of business that is in great demand, this is evidenced by the largest number among other forms of business. Apart from that, these MSMEs are also very popular because they are considered quite strong in facing the economic crisis so that the role of UMM in encouraging the development of the country's economic growth is very significant. MSMEs also have many other advantages which are related to optimizing the use of national resources. But unfortunately, the great potential of these MSMEs has not been utilized properly, even though this sector has long been the foundation of $92.72 \%$ of the workforce outside the government and large businesses so that these MSMEs should occupy an important place in the post-crisis Indonesian economy. ${ }^{2}$ Apart from that, there are still a lot of MSMEs in Indonesia that have not received business legality or formalities. The formalization of business here is the granting of permits for certain business activities and also the status of a legal entity for MSMEs in accordance with existing laws and regulations.

A license itself is a form of legal action which is applied into regulations based on requirements and procedures in accordance with statutory provisions. License is also a form of approval from the competent authority for the operation of a business activity carried out by a business actor. This business license is very important for every business so that it can facilitate and also launch business activities so that every business actor is required to be able to administer and have a business license 2 Noer Sutrisno, "Implementasikan Catatan Untuk Majukan UMKM, Bisnis Indonesia",
2009. 
issued by a government agency. ${ }^{3}$ So, that based on the background description above, the writer formulates the problem formulations, namely: 1). How is the Legality of a Good Product?; 2). How is the implementation of the legality of MSME products in Lerep Village?

\section{B. Method}

The writing of this article uses an empirical legal research method which looks at and also examines how the law works directly in a community environment. And in the process of writing this article, the author also directly examined the legality of MSME products in Lerep village.

\section{Result and Discussion}

\section{Product Legality}

As previously explained regarding Permits or Permits which are a form of approval or granting of permission from the competent authority for the implementation of a business activity by an entrepreneur or a company. These Micro, Small and Medium Enterprises are required to complete their personal data with business legality in the form of a Business License, Proof of Registration or Proof of Data Collection. This business license is very important, especially for Micro, Small and Medium Enterprises because with this Business License, MSMEs can be protected, get legal confidence in enjoying comfort and security, can contribute significantly in increasing the added value of production, providing goods and services for the needs of the community, employment and dissemination of entrepreneurship development. ${ }^{4}$

In addition, by registering and also having a business license also has certain objectives from the community side and also from the government side. The purpose of licensing from the government side is such as to implement regulations regarding whether the provisions contained in the regulation are in accordance with the practice in life or not at all; as a source of regional revenue, because the request for a business license application will directly increase government revenue. Then in addition to that, the purpose of licensing from the community's

3 As stated on Peraturan Menteri Perdagangan RI Nomor: 46/-DAG/PER/9 tentang Penerbitan Izin Usaha (Jakarta: 2009).

4 Heri Kusmanto \& Warjio, "Pentingnya Legalitas Usaha Bagi Usaha Mikro Kecil dan Menengah”, Jurnal Pendidikan Ilmu-Ilmu Sosial, Vol. 11 No. 2 (2019). 
point of view is to obtain legal certainty, to obtain certainty of rights, to obtain facilities. ${ }^{5}$

The business license required by business actors varies, depending on what type of business midwife the company will cover. Types of business legality:

1) Micro and Small Business License (IUMK)

2) Trading Business License (SIUP)

SIUP is a permit issued by the minister or authorized official who has been appointed to issue a license to entrepreneurs to be able to carry out business activities in the trade and services sector. This SIUP is given to entrepreneurs, both individuals, CV, PT, cooperatives and so on. ${ }^{6}$

3) Business Place Permit (SITU)

A Business Place Permit is a letter used to obtain a business license in a business location with the aim of not causing disturbance or loss to certain parties. This place of business permit is stipulated in the regional regulation of the domicile of the company concerned. And the basis for the ownership of this place of business license is regulated in regional regulations in each region. ${ }^{7}$

4) Barcode

A barcode is an arrangement of black and white vertical print lines with different widths and shapes which functions to store specific data such as production codes, identity numbers and others. The use of these barcodes can be found in shops, supermarkets or supermarkets to help track the items purchased and generate prices and previous data that have been programmed through data entry (database). The use of barcodes functions in retail purposes, one of which is UPC (Universal Price Codes), which are usually used for the purposes of products sold in supermarkets; then the use of barcodes for packaging which is usually used for delivery of goods; barcode for control purposes which is often used in product control, for example a barcode that shows the International Standard Serial Number (ISSN) of a book. In addition, Barcodes in use in the pharmaceutical field are to identify a medicinal product.

\footnotetext{
5 Adrian Sutedi, "Hukum Perizinan Dalam Sektor Pelayanan Publik", Jakarta: Sinar Grafika,p 20.

6 Peraturan Menteri Perdagangan RI Nomor: 46/-DAG/PER/9. Tentang Penerbitan Izin Usaha.

$7 \quad$ Ibid.
} 
5) Brand

Definition of Mark according to Article 1 of Law Number 15 "A mark is a sign in the form of a picture, color arrangement, name, word letters, numbers, or a combination of these elements which has distinctive power and is also used in trading activities of goods or services. ${ }^{8}$

6) BPOM

The Food and Drug Supervisory Agency (BPOM) is an institution in Indonesia that is tasked with overseeing the distribution of drugs and food in Indonesia. An effective and efficient drug and food control system (Sis POM) capable of detecting, preventing and controlling products with the aim of protecting the safety, safety and health of consumers both at home and abroad. For this reason, a POM has been formed which has national and international networks as well as law enforcement authority and has high professional credibility. According to the regulation of the head of the Indonesian food and drug supervisory agency number HK.00.05.1.23.3516 concerning the distribution of medicinal products, traditional medicines, cosmetics, supplements and food.

7) Label

Labels are text, images, or a combination of both that is included in the container or packaging of a product by inserting it into, pasting or printing and is part of the package. 9 The existence of a label on a product is very important. This is because the label is the identity of a product so that with a label, consumers can differentiate between one product and another. In addition, consumers can also get products according to what they want. The existence of a label can also eliminate consumer doubts in buying a product. ${ }^{10}$

\section{Implementation of Product Legality in Lerep Village}

Legality for a product is certainly very important for MSME business actors everywhere, in order to make it easier for them to market their products. In addition, it is also intended to provide clarity of legal protection for business actors and their products. But for those who carry out their UMKM business activities in the village, they may still have a little understanding or difficulty in obtaining Product Legality for the

Undang - Undang Republik Indonesia Nomor 20 Tahun 2016 tentang Merk.

Feri Kusnandar, "FAQ Tentang Pangan Halal", Bandung: Departemen Ilmu Teknologi Pangan -IPB. 2010. Diakses dari http://itp.fateta.ipb.ac.id. Accessed on 18 March 2021. 
Products they produce in making them a business facility. MSMEs need to receive special protection in facing the free market. The protection that is expected is in the form of, among other things, strengthening the capacity of human resources, capital, training, promotion, and a conducive business climate. With the existence of Presidential Regulation Number 98 of 2014 concerning Licensing for Micro, Small and Medium Enterprises, the license for MSMEs is only 1 sheet and can be issued in only 1 day by the sub-district. With a permit that can be completed in a day, MSMEs can get four benefits. First is business legality, second is the ease of obtaining capital because it is legal, then access to business assistance from the government, and fourth is the opportunity to obtain empowerment assistance from the government.

The implementation of this ease of licensing for MSMEs is still not possible in all regions because there are still regional heads who have not issued regulations to delegate the authority to issue MSME permits to districts. ${ }^{11}$ So that the business runs well and has clear legality. Of course, there needs to be an official permit from the government. Nowadays, many MSME businessmen ignore this one thing. Most of them think that licensing is only needed by businesses that are already moving on a large scale. Licensing is the granting of legality to a certain person or business actor / activity, either in the form of a license or a business registration certificate. Permits are one of the most widely used instruments in administrative law, to control the behavior of citizens. ${ }^{12}$ The public feels that the products of legislation regarding licensing and non-licensing management in various government agencies still prioritize the culture of official power, overlapping regulations, are bureaucratic, not transparent and often illegal levies occur. Therefore, the arrangement of licensing and non-licensing management is needed. ${ }^{13}$

Referring to Law No. 20 of 2008 concerning MSMEs, the concept of micro, small and medium enterprises has many meanings: first, businesses that are established for the purpose of economic activity and not for non-profit activities: second, businesses that are productive or generate profits or profits from business, third, an independent or independent business that is not part, branch, or affiliate of another business: and the four businesses that are owned by individuals or business entities. The application of product legality

11 Heri Kusmanto, Warjio, "Pentingnya Legalitas Usaha bagi Usaha Mikro Kecil dan Menengah” Jurnal Pendidikan Ilmu - Ilmu Sosial, Vol. 11 No. 2 (2019): 321 - 322

12 Philipus M. Hadjon, 1993, Pengantar Hukum Perizinan, Surabaya: Yuridika, p.2.

13 Juniarso Ridwan, 2009, Hukum Administrasi Negara dan Kebijakan Pelayanan Publik, Bandung: Nuansa, p.99. 
in this village is usually a little difficult because residents are not easy to get business permits or product legality permits from the local government in running their MSME businesses. According to the data that occurred in the field itself, the legality of the products contained in the MSMEs in Lerep Village still does not meet the requirements for running a business because of the lack of socialization from the government regarding the legality of the product and the awareness of residents who are MSME business actors in implementing legality in products. Because basically knowledge of legal aspects in entrepreneurship is also something that needs to be considered, because the status of a legal entity is an important basis when doing entrepreneurship.

Therefore, the company must have a certain legal entity in order to have legality in carrying out its activities. The objectives of licensing or product legality of a business are $:^{14}$

a) From the government side Through the government side, the objectives of granting permits are:

1) To implement regulations whether the provisions contained in the regulation are in accordance with the reality in practice or not and even to regulate order.

2) As a source of regional income with a request for a permit application, the government revenue will directly increase because each permit issued by the applicant must pay a levy first. The more income in the field of retribution, the final goal is to finance development.

b) From the community's point of view, from the community's point of view, the purposes for granting the permit are as follows:

1) For legal certainty.

2) For certainty of rights.

3) To obtain facilities after the building has a permit.

By tying actions to a licensing system, law making can serve the multiple purposes of a permit.

As for the convenience of legality is part of MSMEs, namely, the legality statement provides information that the product has been registered with the Food and Drug Supervisory Agency (Badan POM), in the form of a registration number code. MD and SP codes are for local food and ML for imported food. However, there are still many products that are labelled halal, but are not registered as products that have been certified halal, this is especially so for products that have an SP code or are not coded at all. So for such products, according to Apriyanto, it is consumer knowledge that

14 Adrian Sutedi, 2011, Hukum Perizinan Dalam Sektor Pelayanan Publik, Jakarta: Sinar Grafika, p. 200 
determines whether their halalness is doubtful or not, if in doubt, the best attitude is not to buy products that are questionable halal. In other words, the legality of products in the company must be legal according to laws and regulations, where the company is protected or covered with various documents until it is legal in the eyes of the government in power at that time. ${ }^{15}$

\section{Conclusion}

In essence the legality of a product is indeed very important and necessary in running a business, because the benefits that can be taken will be many if a product has obtained its legality in running its business, so the government should be even more diligent to appeal to MSME actors in making their products become legal product. MSME that has the legality of its company, the entrepreneur has received guarantees for the sustainability of his company, such as having legal protection, promotion facilities, proof of legal compliance, making it easier to obtain a project and facilitate business development. This business license is very important for every business so that it can facilitate and also launch business activities so that every business actor is required to be able to manage and have a business license issued by a Government Agency.

\section{E. Acknowledgments}

None.

\section{F. Declaration of Conflicting Interests}

The authors states that there is no conflict of interest in the publication of this article.

\section{G. Funding}

None.

\section{H. References}

Heri Kusmanto \& Warjio, W. 2019. Pentingnya Legalitas Usaha Bagi Usaha Mikro Kecil dan Menengah. Jurnal Pendidikan Ilmu- Ilmu Sosial. Vol 11 No. 2

15 Janes Sidabalok, 2012, Hukum Perusahaan: Analisis Terhadap Pengaturan Peran Perusahaan Dalam Pembangunan Ekonomi Nasional di Indonesia, Bandung: CV.Nuansa Aulia p. 3 
Irfani \& Nurmaya Safitri. 2020. "Perizinan Terhadap Usaha Mikro Kecil Menengah (UMKM) Yang Melakukan Pencemaran Lingkungan". Jurnal Al' Adl Vol. XII No. 2.

M. Hadjon, Philipus. 1993, Pengantar Hukum Perizinan, Surabaya: Yuridika.

Peraturan Menteri Perdagangan RI Nomor: 46/-DAG/PER/9 tentang Penerbitan Izin Usaha.

Ridwan, Juniarso. 2009, Hukum Administrasi Negara dan Kebijakan Pelayanan Publik, Bandung: Nuansa.

Sidabalok, Janes. 2012, Hukum Perusahaan: Analisis Terhadap Pengaturan Peran Perusahaan Dalam Pembangunan Ekonomi Nasional di Indonesia, Bandung: CV.Nuansa Aulia.

Sutedi, Adrian. 2011, Hukum Perizinan Dalam Sektor Pelayanan Publik, Jakarta: Sinar Grafika.

Sutedi, Adrian. 2011. "Hukum Perizinan Dalam Sektor Pelayanan Publik". Jakarta : Sinar Grafika.

Sutrisno, Noer. 2009. "Implementasikan Catatan Untuk Majukan UMKM, Bisnis Indonesia".

Undang - Undang Nomor 20 Tahun 2008 tentang Usaha Mikro, Kecil dan Menengah.

Undang - Undang Nomor 20 Tahun 2016 tentang Merek.

Wardani,Susilo. 2017.Kebijakan Perizinan Pengembangan UMKM Sebagai Upaya Mewujudkan Negara Kesejahteraan Di Era Liberalisasi Ekonomi Global. Jurnal Publikasi Ilmiah : 122-141. 